\title{
Practicing Care in Teenage Mother Support Groups
}

\begin{abstract}
This paper draws on two qualitative research projects with teenage parents and examines their use of support groups. It argues that group-based programmes such as the ones discussed here convey particular advantages in providing support for young parents which may not be possible in a one-to-one context. This includes peer learning, the development of friendships as a form of social support and respite. This paper argues however, that for these potentials to be realised, an underpinning ethic of care is required. Using Joan Trontoô four phases of care (caring about, caring for, caregiving and care receiving) and their concomitant elements (attentiveness, responsibility, competence and responsiveness) the practices of the group leaders in providing support are analysed. The paper concludes by arguing that óvriting inôan ethic of care approach to policies designed to support teenage parents would be beneficial for service provision.
\end{abstract}

\section{Key Words}

Ethic of care; peer support; social support; teenage parenting; 


\section{Introduction}

An understanding that teenage parenthood constitutes a significant social problem has informed social policies under both this and previous governments. This is grounded on a number of negative outcomes linked to teenage parenting including poverty (Berthoud and Robson 2001), poor educational outcomes (Hosie 2007) and ill-health for children (Botting et al 1998). These issues are not an inevitable result of teenage parenting but have been linked to socioeconomic status and are often a precursor to teenage pregnancy (Hawkes et al 2004; Wiggins et al 2005; Arai 2009). However it is important to consider the possibility that teenage pregnancy can have a compounding effect on previously existing disadvantage (Hawkes et al 2004; Daguerre and Nativel 2006). Nonetheless, social support can alleviate some negative outcomes. For example, good quality ante-natal care reduces, if not eliminates, many health risks (Macintyre and Cunningham-Burley 1993; Irvine et al 1997; Botting et al 1998). Similarly, good postnatal support can reduce health risks, improve childcare and nutrition (Sarri and Phillips 2004) and specialist educational units for young mothers can aid positive educational outcomes (Dawson 2006; Hosie 2007). It is therefore important to formulate an understanding of how to engage and work with young parents successfully and to think about what kind of support is best placed to improve their lives and those of their children.

This paper argues that group-based programmes providing holistic care are a particularly beneficial way of supporting young mothers. Such approaches provide opportunities to reduce isolation, facilitate peer learning and afford time for women to focus on their own needs, as well as those linked to their mothering role. The paper draws on ethnographic research conducted in three young parents groups operating under the Teenage Pregnancy Strategy (TPS) and a follow-up study focusing on the groups themselves. This paper therefore joins others in this area (see Yardley 2009 and Rudoe 2014) to provide a record of work conducted by the TPS and some understanding of ávhat worksô

\section{Applying an 'Ethic of Care'}

This paper also takes an ethic of care approach. Where others have discussed care ethics in relation to disability and health (Barnes 2006; 2012), work/life balance (Williams 2001) and ageing (Sevenhuijsen 2003) this paper argues that an ethic of care has value for the support of teenage parents. Care ethics were first developed by Carol Gilligan in 1982 as a challenge to an assumed male model of moral reasoning (Koggel and Orme 2010). This feminist approach to ethics has been much debated and expanded since although core elements of Gilliganôs arguments remain. For instance, that the self is intrinsically interdependent (Sevenhuijsen 2000) and that individuals are ñot the isolated and abstract entities described in traditional liberal theoryò (Koggel and Orme 2010:110). This perspective therefore substitutes independence with an acknowledgment of care as a necessary element of society (Sevenhuijsen 2003). However, these ideas sit in opposition to current Western values of independence and self-reliance (Lloyd 2010) and care currently occupies a marginal space in society (Tronto 1993). Sevenhuijsen (2000) has argued that a solution may lie in ensuring that citizens have a constitutional right to care or by integrating care into social policies, the 
social infrastructure and institutions of civil society. Furthermore, in order to provide ógoodô care, we need to take into account the perspectives of the care-givers and care-receivers and ğudge with careô(Sevenhuijsen 1998).

Joan Trontoôs work draws on these ideas. Writing with Fisher in 1990, these authors argued that the motivation to care does not inevitably lead to the provision of good care. They point out that care is a practice requiring a balance of skill, time, knowledge and resources. There therefore remains a need to set out a process of care. Such a process can provide a guide for how we do caring work as well as providing a framework for political change (Tronto 1998). With this in mind, Fisher and Tronto (1990) identified four phases of care: caring about, caring for, caregiving and care-receiving. Within these, Tronto (1993:127-135) provides details of four ethical elements which further help to describe the practice of care: attentiveness, responsibility, competence and responsiveness. It is these phases and their concomitant elements which underpin the analysis made here.

ócaring aboutôis an orientation to care (Fisher and Tronto 1990) or as Tronto (1998) later puts it, the process of becoming aware of care needs. Attentiveness is therefore required in order to notice needs. It is, according to Tronto (1993), the first task of humans from the standpoint of an ethic of care. Inattentiveness (or ignorance) could therefore be considered a óform of moral evilô(pg127). The second phase áaring forô is the point at which responsibility is taken for the meeting of the care need. Tronto (1993) argues that responsibility is assumed not on the basis of a set of rules or an obligation but out of implicit cultural practices. Care needs may not be met if left solely to duties and obligations. The third phase áaregivingôinvolves the practical provision of care and so requires ćompetenceô That is, the caregiver needs both commitment and skill in order to understand what is needed (Fisher and Tronto 1990). As Tronto (1993:133) suggests, óntending to provide care . . but then failing to provide good care, means that in the end the need for care is not metô Finally, áare receivingôentails responsiveness in that the care receiver responds to the care. The caregiver then needs to take action as a result of that response as new or different needs of care may have arisen, or the care provided may not have met needs (Tronto 1998). The caregiver is therefore required to act reflexively. Furthermore, requiring care places a person in some vulnerability to which the caregiver must be alert. As Tronto (1993:133) argues, the moral element of responsiveness requires carers remain aware of and guard against ñthe possibilities for abuse that arise with vulnerabilityò. Good care requires all four phases and their associated elements to come full circle and form an óntegrated holistic processô(Tronto 1998). Care is then a practice which takes into account the full context of caring, the needs of the care receiver as well as the skills and resources of the care giver. Tronto (1998) recognises this as is an ideal form of care and there are significant challenges in achieving ógoodôcare; for example, the ability to balance the demands of numerous care receivers and institutions or a lack of resources.

Trontoôs phases of care are particularly useful for this level of analysis of service provision. They allow us to consider what ógoodôcare may look like and prompt us to think about care as a set of moral principles which can guide conduct (Barnes 2012). Tronto and Fischerôs process also provides a practical approach to care which focuses on micro-level caring 
relationships (Lloyd 2010). This enables us to look at the implementation rather the design of support strategies. Looking at care provision through this lens can therefore help us make some assessment of the support giving to teenage parents and consider how best to improve on support strategies. Consequently, it is with these four phases and their constituent elements that I analysed the practices and decisions of the group leaders.

This paper will now provide some policy context before going on to describe the research process. This is then followed by a discussion of the findings in which the groupsôsupport are considered before demonstrating how they were underpinned by an ethic of care.

\section{The Policy Background}

Shortly after being elected in 1997, the incoming Labour government commissioned a report into teenage pregnancy which culminated in the creation of the cross-departmental Teenage Pregnancy Unit. This, in turn, implemented the TPS. The Strategyôs two main aims were to reduce the incidence of teenage pregnancy (specifically to halve it by 2010) and support those who did become teenage parents. It is the support element of the strategy which is of interest here.

The support arm aimed to reduce long-term social exclusion of teenage parents and their children, reduce repeat pregnancies and increase numbers engaging with education, employment and training (EET). One of the ways in which support was offered was through group-based interventions similar to parent and toddler groups. It was in three such groups that this author was researching at the tail end of the TPS (2008-2010). During the finishing stages of the research, the Conservative/Liberal Democrat Coalition government came to power. At this point the TPS (originally conceived to run for ten years) was due to come to an end and the incoming government accordingly discontinued the strategy. Instead, the key support mechanism for teenage parents would be delivered via the Family Nurse Partnership (FNP). The FNP is a programme modelled on a US approach which consists of one-to-one home visits from a health professional. The scheme focuses primarily on health and parenting but also considers interpersonal relationships and EET (Department for Education 2012).

It was the removal of the overarching strategy and ring-fenced funding that, in 2011 , led to the closure of two of the groups this author was researching with ${ }^{1}$. This paper considers service provision prior to the changes described here. The following section will now go to describe the research process before reflecting on the benefits of group support.

\section{Research Process}

\section{Study One}

This study examined key álecisionsôand áchoicesômade by young women as they became mothers and was conducted at three young parent support groups in the South of England. The groups themselves were not the explicit focus of this study; nonetheless, it yielded

\footnotetext{
${ }^{1}$ The third group was charity run and was taken over by the local Primary Care Trust in 2011. It closed some time later.
} 
substantial data on the womenôs experiences of the groups and the ways in which they ran. I therefore returned to this data and analysed it anew in order to understand the role of the groups in more detail. The research was ethnographic in design and consisted of participant observation conducted at weekly meetings for period of a year. The second stage consisted of two focus groups and a series of qualitative semi-structured interviews with young parents attending the groups. In total, twenty-one young mothers were interviewed.

\section{Study Two}

This study focused on perspectives of the groups from those who accessed and delivered the service and aimed to supplement findings from the first study via qualitative interviews. This sample consisted of two group leaders, one volunteer leader (who had also attended as a young mother) and four young mothers. As Mills et al (2013) found, contacting participants to arrange an interview or having them contact me was often unsuccessful. I had faced similar issues with recruitment in the first study, however, with the groups as a meeting point I had been able to overcome this issue (as were Mills et al) but with the groups disbanded, this opportunity no longer existed. Leaders were either difficult to locate or could not take part due to restrictions of their continued employment for the LA/NHS. Nonetheless, together with the first study, there was sufficient data for analysis.

Both datasets were analysed through a process of thematic analysis. I did not set out to analyse the groups from an ethic of care perspective. Instead, and similar to Barnes (2012), I started from the position of examining lived experiences. I had no pre-set themes beyond considering support offered by the groups. Approaching analysis in this way I began to see that whilst the remit of the TPS was linked to notions of support (by this I mean support to fulfil aims such as engaging with EET) it was care which underlay decisions specifically made by the group leaders. It was then that I began to consider the rationale and purpose behind the groupsôprocedures and practices and to formulate ideas around care ethics. Additional themes did emerge from the data (for instance ácharismatic leadershipô but those discussed here are those considered to be particularly salient to ethic of care practices.

\section{The Groups}

\section{Newtown and Pensford}

Newtown and Pensford groups were both run by the LA and held in two separate small towns. The groups met weekly for two hours during term time. Both groups were run by the same leaders; a óProject Leader for Young Parentsô(Lily) and a óYoung Parent Workerô Each group was attended by approximately 8-15 mothers (attendance and composition often varied) and included mothers up to the age of twenty-three. The groups were ávomen onlyô as it was felt this would allow them to address issues specific to their needs and talk openly. The groups were linked to a third álosedôgroup also run by the Project Leader. Women attended this group by referral only and dealt with more specific issues such as depression or domestic violence. 
Both groups had a large area, plenty of supplies, a varied timetable of activities and were supported by a crèche. Activities included cooking, sex and relationship discussions, arts and crafts and games mornings. The women were also visited by a range of professionals including a life coach, fire-fighters, a chef and college lecturers. Within these activities the leaders were able to address many of the aims of the TPS, for instance reducing the numbers of subsequent pregnancies or improving knowledge of nutrition.

\section{Minton Antenatal and Postnatal Groups}

Minton was a charity funded group held weekly for two hours. It ran in the centre of a city and consisted of an antenatal and a postnatal group held at the same time in adjoining rooms. The antenatal group was run by Myra (the groupsôfounder) and a Teenage Pregnancy Midwife. It ran on a nine week cycle with the Midwife covering classes on birth and pain relief. Myra then ran sessions on baby care, financial planning, contraception and relationships. When not in the antenatal group, Myra assisted in the postnatal group which was also attended by two Young Parent Workers and a Health Visitor. The attendance and composition at the postnatal group fluctuated between 10-15 young parents. Fathers were welcome, but mothers were the most regular attendees. Minton antenatal group was usually smaller with between 5-10 expectant mothers and their partners in attendance.

There was no crèche facility although there was a small play area for toddlers. A typical group meeting would start with lunch. This part of the session was informal and a time for catching up with friends. Activities followed and could be fun or educational and were sometimes crafts or games the parents could do with the children. The group also had talks on domestic violence, relationships, weaning and child safety. Occasionally the group went on trips including the local swimming pool, aquarium or library.

\section{Support Practices}

This section draws on the practices of these groups in order to illustrate some of the benefits experienced by the women in attendance. Data is presented thematically as; q́peer learningô óriendshipô and órespiteô Excerpts from data are coded thus:

FN (field notes)

S1 (study one)

S2 (study two)
M (Minton)

P (Pensford)

$\mathrm{N}$ (Newtown)

\section{Peer Learning}

As illustrated above, many of the groupsôactivities were focussed around learning. Sessions were run by the leaders themselves, relevant professionals or teenage mothers. For example, mothers from Minton post-natal group often came into the ante-natal group to share childbirth experiences. Another group were making a video to promote breastfeeding to other 
young parents. In the Pensford group, one young mother, Anastasia, was asked to return to the group as a volunteer leader. Anastasia had left a violent relationship with the help of the group leaders and the services to which they had referred her. One of her roles was to use this experience to mentor young mothers in abusive relationships. As Anastasia reflects, mentoring required learning a range of skills from which she also benefitted:

I got to not just help the mums but for me as well, I got to do the child protection courses and obviously it gave me experience and to prepare me to go back into work when [daughter] was at school but it was a benefit for me and the other mums

Although in this case peer learning was set up as an intervention, its occurrence was often much less formal. Anastasia reported that she often picked up and shared information through conversations rather than running specific sessions. Other mothers also took it upon themselves to educate and support some of the younger women:

é itôs good for someone my age to talk to peopleé I say ó bet youôe sitting there going ớa la laô itôs going in one ear and out the other, but you know what? When I was sat in your position and I was told exactly the same thatôs all I done, and I tell you what, I wish I listenedô(Nancy:M:S1)

As others have found peer learning can be a successful method of teaching. For instance, in her investigation of sex education classes delivered by young mothers, Kidger (2004a) found that they were considered more trustworthy and easier to relate to than professional educators. This is especially important given that professionals can often be viewed suspiciously by young parents. Indeed, young parentsômistrust of state officials (such as social workers) was a key reason behind the adoption of the FNP in the UK; health professionals were considered to be more able to reach out to young parents (Dodds 2009). Nonetheless, I did observe resistance to health professionals:

[She] told the other girls not to listen to a thing midwives say áhey only know facts, not about your babyô She said ógnore them when they say your baby is overweight and put it on a diet, they donâ know what theyôe talking aboutô[another young mother] vehemently agreed with this, ógeahôshe said ólonâ let anyone tell you what to do with your babyô(FN:M)

Given this, it is important to consider the potential that peer learning may also pass on negative attitudes as well as wrong or partial information. This is, of course, a problem of peer learning in any forum (or indeed outside of a formal situation). However, in this context, the groups contained multiple leaders, volunteers and visitors. There was then at least someone from whom the women would accept advice or could confide in. For instance on one occasion a young mother referred to the health visitor present as áhat bitchô As result of her sharing her feelings with me, I was able to mediate between the health visitor and the young woman (FN:M). Furthermore, the advantages of group working means that peer learning can be formalised. Mentoring schemes, such as that implemented by the leaders at Pensford, mean that young parents are working in partnership with health professionals and support workers. Such collaborations mean that teaching methods and content are more 
relevant to young parents whilst also improving relationships between caregivers and carereceivers.

\section{Friendship}

The activities in the weekly group meetings were not always directly focused on learning. Craft mornings were frequent and provided a focus which allowed talk to flow easily. During these mornings the women chatted and shared stories. Nadine referred to this as an opportunity to órentô I observed órentingôas the women discussed partners, children, in-laws and social services. These shared experiences engendered a sense of not being alone:

Itôs nice to be able to vent it to someone and think óh, well if theyôve done it as well, it canâ be too wrong because Iôm not the only one whoôs made that mistakeôand it sort of makes it easier to deal with (Nadine:N:S1)

é it was just nice to be able to talk to other people and realise youôe not the only one going through it but also thereôs other young people out there too (Ally:N:S1)

Young parents often lose touch with friends after having children (Alldred and Miriam 2010) and tend to be housed away from their existing social networks (Kidger 2004).

Unsurprisingly then, isolation and loneliness are recognised areas of risk for young parents and have been linked to postpartum depression (Mills et al 2013). Conversations regarding anti-depressants as well as the visibility of self-harm scars indicates that many of the women were indeed struggling with mental health issues. A sense of isolation was also apparent; at one meeting at Newtown a young woman who usually attended Pensford arrived:

é she said it was because she was lonely and fed up with being pregnanté another said she leaves the house at 9 and rarely comes back before dinner. Itôs because Iôm lonely said one and there was a general murmur of agreement (FN:N)

During another session the women were asked to list the key relationships in their lives:

é said she had no friends, no one she could talk to outside of family and her partneré .another girl later said that she misses school for the social element. She said she never gets the chance to óbe socialôanymore (FN:N)

The groups therefore provided a vital space to form friendships:

I had the family outreach worker for a while but itôs not the same because they just come and help you in your home, theyôe not a group where you can go and meet other people (Ally:N:S2)

I look forward to ité Iôre made some more friends which is good (Cheryl:M:S1)

Whilst, in policy terms, social inclusion is often reduced to paid employment (Levitas et al 2007), Kidger (2004) points out that óelational inclusionôalso requires attention. For mothers in general, friendships with other mothers can be a vital source of ñsupport, validation, identity and pleasureò (Cronin 2015 forthcoming). For teenage parents, such friendships may be all the more important. As noted above, young parents often lose touch with prepregnancy friends. Furthermore, the stigma of teenage motherhood (perceived or 
experienced) can prevent them accessing more generic groups for parents and toddlers (EllisSloan 2014). Groups such as the ones discussed here can therefore be an important means to improve óelational inclusionô Friendships should not therefore be looked at as a pleasant byproduct of group working, but a key means by which young parents can receive support and an antidote to stigmatising representations of teenage motherhood. As these women note, shared experiences of youthful parenting can engender a sense of belonging and normality:

I probably would prefer to go out with them [women from the group] than with my old friends because weôe got a lot more in common (Holly:P:S1)

I think itôs having these groups to go to where there are other young mums and sort of, not sharing the role of childcare but sort of going out as a group of girls with the children in the buggies. Itôs a way of, I donâ know, itôs a way of... knowing thatôs quite normal (Nadine:N:S1)

\section{Respite}

As noted above, both Newtown and Pensford groups had a crèche facility. This provided the women with a dedicated two hour respite from the demands of parenting. For many of the women, particularly those who were also single parents, this was the only break they had all week:

Itôs nice to have two hours to myself and just to be able to sit and chat about anything reallyé and have a laugh. Itôs the only thing I do during the week (Kate:P:S1)

I could be myself a little bit and have support and have a little bit of time for myself while [daughter] was in the crèche and just have some time with other people (Anastasia:P:S2)

é it was nice to have a little while to myself in the week knowing as well that [son] was enjoying it and it was really benefitting him (Holly:P:S2)

As Holly indicates, the crèche was important for the children as they were able to access equipment and resources not otherwise available to them. Crècheôs also enable children to socialise and develop good communication skills prior to starting school (Hendessi and Dodwell 2002). Importantly, the crèche was also significant to the provision of effective support for the women. Firstly, this meant that activities could focus on the womenô, rather than the childrenôs needs. Sessions involving cooking lessons, sex education and first aid training were therefore enabled. Secondly, activities were uninterrupted. As noted above, Minton had no crèche facility. As a result, and despite the best efforts of support workers to keep children occupied, sessions were often disturbed. Women also had to break away at various intervals to attend to the needs of their children. Thirdly, the absence of children allowed the women to talk openly about their lives and relationships. Anastasia, for instance, spoke out about her violent relationship for the first time at the group. She argued that this would not have occurred had her daughter been present and felt that others would have similarly been deterred from reaching out for support: 
... it wasnâ just a case of you just sit there and you know state it as a matter of fact $\ddot{i}$ you sit there and you cry and you get emotional and you canâ do that when there are children there

Furthermore, the groups (and particularly the notion of them providing a óreakô) appear to have been beneficial for mental health:

I suffer with post-natal depressioné and I get really stressed outé Iôm finding it hard. Itôs just sort of like you do need a break and like in the summer holidays I didnâ even have this to come to (Ally:N:S1)

I think having the group has really helped because I did suffer really badly from postnatal depression and the ante-natal group has really helped. Having somewhere to go, knowing that Iôve got someone around me to help me and I can go to if I need to, and a break when I need one (Jill.:M:S1)

The experiences of these women arenâ isolated and reflect the prevalence of mental health issues amongst teenage mothers in general (Berrington et al 2005). However, social support has been found to be important in alleviating mental health issues (Mills et al 2013). These outcomes are therefore significant.

Respite, in itself, is not predicated on the absence of children however. Even without the crèche at Minton, Jill (above) referred to the group as a óreakô Mills et al (2013) found that groups for young mothers with children present provide respite because they offer an opportunity to get out of the house and dilute the childrenô focus from solely being on the mother. Nonetheless, a crèche adds significant value to support groups by enabling young mothers to concentrate on their own needs and participate fully in activities (Hendessi and Dodwell 2002).

This paper has outlined the practices of three young parents groups. It has shown how support can encompass group activities (for fun or learning), trips and opportunities to socialise. The data has been used to argue that group working enables peer learning, the development of friendships and respite from parenting. This paper therefore joins others in arguing that group working is an important method of support for young parents (De Jonge 2001; Yardley 2009). Such arguments are timely; despite positive outcomes of FNP being reported, the approach is not unproblematic (see Dodds 2009 for a full discussion). Consequently, there remains a need to consider a range of approaches to support young parents. This is particularly important in a context where the future of Childrenô Centres and other potential sources of support are under threat from austerity cuts. Group based support programmes, unlike one-to-one, can aid the development of a long-term support network of peers. Group working can also reach young parents not eligible for FNP or who are unwilling to engage with this form of support and can be used to complement the work done by the FNP to provide a robust and holistic support system for young parents. 


\section{Practicing Care}

This paper makes one additional argument. I argue that the benefits discussed above were enabled because the groupsôpractices were informed by an ethic of care. For instance, the practices described above came about because group leadersôdecisions were primarily underpinned by a desire to understand and meet the womenôs specific care needs. This section therefore outlines Joan Trontô̂ definitions of care $(1993 ; 1998)$ and demonstrates how they informed the above practices and other care decisions made by the group leaders.

\section{Caring About}

According to Tronto (1998), áaring aboutôrequires attentiveness in listening to articulated needs and recognising unspoken needs. The young women in the second study reflected on the trusting relationships they enjoyed with the group leaders and that they felt listened to:

[Lily] was very intuitive and she knew when you needed some support, she knew when you needed to be left alone, she never pushed anything, she always offered good advice and could always point you in the direction to services that would be of use to you (Anastasia:P:S2)

There was always someone there if you needed a private talk, then you could pull them out (Ally:N:S2)

It was good to have someone whoôs going to listen and give you good advice (Chelsea:N:S2)

Trust cannot be taken as a given however. As noted above, a lack of trust in some health professionals and social workers was often observed. This is not to say that the professionals the women came into contact with did not care, but that having time to prioritise care and work on caring relationships is integral to the development of trust. Time, space, emotional energy and a willingness to sustain connections is required (Sevenhuijsen 2003; Barlow et al 2005). However, allocating time to establish relationships is often dismissed as nonproductive by service managers (Barlow et al 2005).

áCaring aboutôalso requires distinguishing between needs and deciding which needs to care about (Tronto 1998). It is therefore about applying what has been learnt from listening attentively including to unspoken needs. For instance, the focus on friendship and respite discussed above were not required by policy and are unlikely to have been needs the women voiced directly. However, the leaders responded to the women and worked hard to develop a group in which friendships could thrive. Friendship and peer support do not emerge simply by providing a group context. Group leaders have a significant role in ñé facilitating an atmosphere of openness and trust between the participating parentsò (Coren et al 2003:101). As discussed above, friendships were an important advantage of the groups for the women and their facilitation appeared to be something that women wanted from the leaders. For instance, Rachel reflected that she would have liked Minton group to have helped the women ñto interact more and talk together as a groupòwhilst Anastasia (P:S2) appreciated how Lily would introduce members of group when she felt they would be able to support each other. 
There were times when the womenôs expressed needs (or desires) conflicted with the aims of the TPS and the leaders had to negotiate that conflict. For instance, one Minton leader, Debbie, expressed concern that teenage mothers, unlike older mothers, were expected to find work or enter education quickly after parenthood. She questioned the wisdom of labelling teenage mothers NEET rather than viewing them as ótay-at-home mothersô Indeed, whilst EET may improve earnings and decrease the likelihood of poverty, we need to think about how these aims fit with the needs of young mothers. For instance, how a need to complete education may fit with a need (and desire) to care for small children. Focusing on EET is not always out of step with the aspirations of young mothers (Yardley 2009) but timing is crucial. As Alexander et al (2010) found, young mothers often feel more willing to return to work or education when their children are in nursery or school and thus considered óreadyôto be left. Debbieôs consideration of the needs of the women not only indicates an ethic of care approach but may also be more successful in engaging young mothers. When young mothers are not ready for EET, pursuing these aims regardless may be at the detriment of a trusting relationship and their needs as mothers. Recognising their need to care and working with them however may mean that there remains a space to work on EET when parenting responsibilities are less demanding.

\section{Caring For}

Tronto (1998) regards áaring forôas the assumption of responsibility rather than care being an obligation. It is certainly the case that the women running the groups were doing so as a job and therefore, to a certain extent had an obligation to care. Nonetheless, this does not preclude a caring relationship. Furthermore, caring occurred beyond the boundaries of the group context and sometimes beyond the remit of the leadersôjob descriptions. All nonattendees at Newtown and Pensford received a follow-up call to check on their well-being. One of leaders at Minton often sourced and hand delivered second hand baby equipment to young families and both Lily and Myra acted as advocates and mediators for the women and even spoke for them during court appearances. The leaders also fought for the womenôs care needs to be recognised and protected on a number of occasions. Observations at all three groups revealed conflicts between the LA and the group leaders. Myra reported how she had to justify the need for groups specifically for teenage parents. Lily often had to deal with complaints from the LA that young mothers get áoo muchô for instance her provision of a crèche. It was considered, by some, an unfair advantage for teenage mothers. As is demonstrated above however, the crèche was a direct result of an understanding of the womenô care needs (as well as those of their children) and led to her continuing with the provision in the face of considerable opposition.

\section{Caregiving}

Tronto (1998) discusses caregiving as the meeting of the care need. This study did not set out to measure outcomes of specific social policies for teenage parents. Nonetheless, the data indicated that care needs were being met by the groups and their leaders. In some cases, this was material (the provision of baby equipment) or in the teaching of skills (such as cooking or first aid). As Holly (P:S2) relates, longer term needs were also addressed: 
é there are girls there that since theyôve been at that group have received help with housing, have received help with getting back into college and getting back into work...they helped with confidence issues, relationship issues, really encouraged me, I did hairdressing, I qualified and they really supported me and helped with the application forms

Without an in-depth and longitudinal study specifically examining groups and the womenôs attainments, claims about óhardôtargets such as returning to education cannot be ascertained. Nevertheless, qualitative data such as that discussed above regarding peer support, friendship and respite provides a good indication that some equally important outcomes were evident. Furthermore, there is an argument to be made that this type of holistic caring work means that policy targets are more likely to be met (McLeod et al 2006). Although the groups all provided a space for considering EET, this was not the only focus. Instead, and supported by the crèche or informal activities, the leaders addressed the womenôs overall well-being. Such an approach recognised that it is unlikely a parent suffering with postnatal depression or trying to find a safe place to live can even begin to consider education or employment.

\section{Care Receiving}

This final phase of care involves responsiveness to how care is received, whether needs have been met and whether caregiving was successful (Tronto 1998). Responsiveness is particularly evident in the involvement of the women in the planning process. As a result, the groups covered areas and activities which were considered ñelevantò(Holly:P:S2) and ñnformativeò(Anastasia:P:S2). At Minton, mothers were asked to provide feedback to funders. This enabled them to reflect on how they felt about the group. As a result of these processes, group leadersôwere able to assess which practices would best meet the needs of young parents and whether current approaches were working. It is this final stage of an ethic of care approach which led to the groups providing a space for respite, the forming of friendships and peer learning which were so evidently well received.

Care receivingôalso requires the caregiver to be alert to the potential for abuse and stemming from vulnerability (Tronto 1993). Considerations of vulnerability are especially important when working with teenage parents. As Sevenhuijsen et al (2003:317) argue, ñé pathologizing notions of care easily turn women into a group with special needs that deviate from those of normal citizensò. As was discussed at the beginning of this paper, the negative outcomes and experiences of teenage pregnancy are not inevitable. Nonetheless, teenage motherhood remains a stigmatised identity, in part linked to suppositions about motives and poor choices as well as outcomes (Ellis-Sloan 2014). However, these presumptions and judgments were not evident at the groups. Here the women were treated as individuals and mothers (rather than simply teenage mothers). Vulnerability was not assumed and where it was evident it was dealt with in a caring and friendly way. The women were able to joke with and tease the leaders, but also received hugs and a shoulder to cry on. As a result, the women expressed a particular fondness for the leaders: 
ñé every week you [Lily] remind me why I come here, itôs the light of my weekò (FN:P)

They were the nicest people youâl ever meet (Holly:P:S2)

\section{Concluding Thoughts}

This paper has highlighted some of the key benefits of working in a group context to support young mothers. It has presented a unique examination of the ways in which a particular form of social support was provided and experienced. This work did not set out to conduct a policy analysis of the ways in which interventions have been formulated and delivered and whether they achieved stated aims. Nonetheless, the qualitative data discussed here provides important documentation of teenage mothersôlived experiences of a policy intervention. It has shown how group-based interventions can engender peer support, peer learning and provide teenage mothers with much needed respite from caring in order that they are cared for. Furthermore, it has been argued that these interventions and the success of their implementation was a result of the leadersôethic of care approach.

Applying this theoretical framework to the analysis demonstrated that the leaders were attentive to the multiple needs of the women. This enabled competent care to be provided in the form of emotional and practical support, interventions, referrals, information and guidance. The leaders developed caring relationships with the women based on openness and trust and nurtured relationships between the women. As a result the women were able to develop long lasting friendships which extended support beyond the group context. The leaders sought to provide care even when meeting particular needs conflicted with policy aims or when it was not required by the TPS, for instance, with the provision of the crèche. Because of this the women were able to gain respite from their parenting roles, have time to ğust beôand to establish friendships. As a result, I argue that the groups were underpinned by an ethic of care and were successful in reaping the benefits of group-working precisely because of this.

It has also been discussed how the Local Authorityôs understanding and support for the groups was not always forthcoming. Indeed, Tronto (1993) refers to the potential for conflict between those on the front line and those defining care needs because of the distance between policy forming bureaucracies and the actual care-giving and care-receiving. It is therefore perhaps not surprising that following the ending of the TPS and ring-fenced funding for teenage parents, the LA decided to close the groups and delete the posts of those who ran them. This decision was met with concern from group leaders and anguish from the parents voiced through petitions, letters to the LA and attempts to engage the local press and MP. Nevertheless, the LA remained resolute and the groups closed in 2011. This paper therefore also hints at what can happen when care needs are not protected. Whilst care for teenage parents is now provided by the FNP, this was not a direct replacement and there was a considerable period where little or no support was provided. Furthermore, the time limited, home-based, one-to-one nature of FNP means that the service (whilst positive) may not best serve everyone and remains an isolated service. 
As Tronto (1993) rather powerfully concludes, inattention to needs is a moral failing when tasked with proving care. Those attending the groups during the closure period may agree:

é It felt like a decision had been made by someone who had no knowledge and experience of exactly how important the groups were and how much they did do for people (Anastasia P:S2)

I donâ understand how they can just take those services away and think we didnâ benefit from them because we did. We put everything in as well to prove that we benefitted from it, therefore our word wasnâ ever taken into consideration (Ally $\mathrm{N}: \mathrm{S} 2$ )

It is perhaps too simplistic to levy such a serious allegation at local authorities who are required to address multiple needs with increasingly limited funding and are forced into making very hard decisions. Nevertheless, it is difficult not to infer from the pre-existing conflict that the inattentiveness exhibited here was as much ideological as financial. Similar to Sevenhuijsen (2000) I argue that care does indeed need to be written into the design and implementation of policies, but also needs to be at the forefront of decision making regarding the removal of services and changes in policy direction. Questions need to be asked as to how care needs will be met if particular services are withdrawn and can only be done when we prioritise the perspectives of care-receivers and caregivers. This primarily reflects an ethic of care approach in which care is valued and placed at the centre of a conception of citizenship and justified as a humane approach. Furthermore, and to use the governmentô preferred parlance of austerity, this may reveal whether removing services are actually more costly in the long term. This may be economically (Hadley cited in Williams 2011), but also in terms of lost expertise and well-established relationships and practices. As Lily concluded; ñThe sad thing is that I know in a while they will be looking to replicate my work, and by then it will be too lateò.

\section{Acknowledgments}

I would like to thank the young mothers who took the time to share their experiences with me and the group leaders who enabled this research to take place and provided considerable support. This work was made possible by a studentship from the University of Brighton.

\section{References}

Alexander, C and Duncan, S (2010). 'Just Mum or Dad': Experiencing teenage parenting and work-life balances. In: Duncan S, Edwards R and Alexander C (eds) Teenage Pregnancy: What's the problem? London: The Tufnell Press, pp: 135-156

Alldred, P and David, M (2010) óWhatô the importance at the end of the day?ôYoung mothersôvalues and policy presumptions In: Duncan S, Edwards R and Alexander C (eds) Teenage parenthood: What's the problem? London: Tufnell Press, pp: 24-46 
Arai, L (2009) Teenage pregnancy: The making and unmaking of a problem Policy Press: Bristol

Barlow, J., Kirkpatrick, S., Stewart-Brown., S and Davis, H (2005) Hard-to-reach or out-ofreach? Reasons why women refuse to take part in early interventions Children \& Society 19(3): 199-210

Barnes, M (2006) Caring and Social Justice Basingstoke: Palgrave Macmillan.

Barnes, M (2012) Care in Everyday Life: An ethic of care in practice Bristol: Policy Press

Berrington, A., Diamond, I., Ingham, R and Stevenson, J. (2005) Consequences of Teenage Parenthood: Pathways which minimise the longterm negative impacts of teenage childbearing. Report, University of Southampton, UK, November

Berthoud, R and Robson, K (2001) The Outcomes of Teenage Motherhood in Europe Innocenti Working Paper No. 86. Florence: UNICEF

Botting, B., Rosato, M and Wood, R (1998) Teenage mothers and the health of their children Population Trends 19-28

Coren E., Barlow, J and Stewart-Brown, S (2003) The effectiveness of individual and groupbased parenting programmes in improving outcomes for teenage mothers and their children: A systematic review Journal of Adolescence 26(1): 79-103

Cronin A (2015 forthcoming) đomestic friendsô womenôs friendships, motherhood and inclusive intimacy The Sociological Review

Daguerre, A and Nativel, C (2006). When Children Become Parents: Welfare state responses to teenage pregnancy Policy Press: Bristol

Dawson, N (2006) In a class of their own? The education of pregnant schoolgirls and schoolgirl mothers. In: Holgate, H., Evans, R and Yuen, F (eds) Teenage Pregnancy and Parenthood: Global Perspectives, Issues and Interventions London: Routledge.

De Jonge, A (2001) Support for teenage mothers: a qualitative study into the views of women about the support they received as teenage mothers Journal of Advanced Nursing 36(1): 4957

Dodds, A (2009) Families óAt Riskôand the Family Nurse Partnership: The Intrusion of Risk into Social Exclusion Policy Journal of Social Policy 38(3): 499-514

Department for Education (2012) Family Nurse Partnership Commissioning Toolkit. Available at: http://www.education.gov.uk/commissioningtoolkit/Content/PDF/Family\%20Nurse\%20Partnership\%20FNP.pdf. (accessed $9^{\text {th }}$ October 2014)

Ellis-Sloan K (2014) Teenage Mothers, Stigma and Their 'Presentations of Self' Sociological Research Online 19(1) 
Fisher, B and Tronto, J (1990) Toward a Feminist Theory of Caring, In: Emily, K and Nelson, M (eds) Circles of Care: Work and Identity in Women's Lives Albany: New York P, pp. $35 \mathrm{I} 62$

Hawkes, D., Joshi, H and Ward, K (2004) Unequal entry to motherhood and unequal starts in life: evidence from the first survey of the UK Millennium Cohort. Report, University of London, UK, November

Hendessi, M and Dodwell, C (2002) Supporting Young Parents: Models of Good Practice Report, YMCA, London

Hosie, A (2007) đ́ Hated Everything About Schoolô An Examination of the Relationship between Dislike of School, Teenage Pregnancy and Educational Disengagement Social Policy and Society 6(03): 333-347.

Irvine, H., Bradley, T., Cupples, M and Boohan, M (1997) The implications of teenage pregnancy and motherhood for primary health care: unresolved issues British Journal of General Practice 47(418): 323-326

Kidger, J (2004) Including young mothers: Limitations to New Labourôs strategy for supporting teenage parents Critical Social Policy 24(3): 291-311

Kidger, J (2004a) óYou realise it could happen to you ô the benefits to pupils of young mothers delivering school sex education Sex Education 4(2): 185-197

Koggel, C and Orme, J (2010) Care ethics: New theories and applications Ethics and Social Welfare 4(2): 109-114

Levitas, R., Pantazis, C., Fahmy, E., Gordon, D., Lloyd, and Patsios, D (2007) The multidimensional analysis of social exclusion, Report. University of Bristol, UK, January.

Lloyd, L (2010) The individual in social care: the ethics of care and the q́ersonalisation agendaôin services for older people in England Ethics and Social Welfare 4(2): 188-200

Macintyre, S and Cunningham-Burley, S (1993) Teenage Pregnancy as a Social Problem: A view from the United Kingdom. In: Rhode, D and Lawson, A The Politics of Pregnancy: Adolescent Sexuality and Public Policy New Haven: Yale University Press, pp. 59-73

McLeod, A., Baker, D and Black, M (2006) Investigating the nature of formal social support provision for young mothers in a city in the North West of England Health \& social care in the community 14 (6): 453-464

Mills, A., Schmied, V., Taylor, C., Dahlen, H., Shuiringa, W and Hudson, M (2013) ósomeone to talk toô young mothersôexperiences of participating in a young parents support programme Scandinavian Journal of Caring Sciences 27(3): 551-559 
Rudoe, N (2014) Becoming a young mother: Teenage pregnancy and parenting policy Critical Social Policy 34(3): 293-311

Sarri, R and Phillips, A (2004) Health and social services for pregnant and parenting high risk teens Children and Youth Services Review 26(6): 537-560

Sevenhuijsen, S (1998) Citizenship and the ethics of care: Feminist considerations on justice, morality, and politics Routledge: London

Sevenhuijsen, S (2000) Caring in the third way: the relation between obligation, responsibility and care in Third Way discourse Critical Social Policy 20(1): 5-37

Sevenhuijsen, S (2003) The Place of Care: The Relevance of the Feminist Ethic of Care for Social Policy Feminist Theory 4(2): 179-197

Tronto, J (1993) Moral Boundaries: A Political Argument for an Ethic of Care Routledge: New York.

Tronto, J (1998) An Ethic of Care Generations 22(3): 15-20

Wiggins, M.,Oakley, A., Sawtell, M., Austerberry, H., Clemens, F and Elbourne, D (2005) Teenage parenthood and social exclusion: a multi-method study, Report, University of London, UK, April

Williams, F (2001) In and beyond New Labour: towards a new political ethics of care Critical Social Policy 21(4): 467-493

Williams, R. (2011) Cuts threaten to undo progress on reducing teenage pregnancies The Guardian, 9 August, 2011

Yardley, E (2009) Teenage Mothers' Experiences of Formal Support Services Journal of Social Policy 38(02): 241-257 